PROCEEDINGS OF THE UNITED STATES NATIONAL MUSEUM

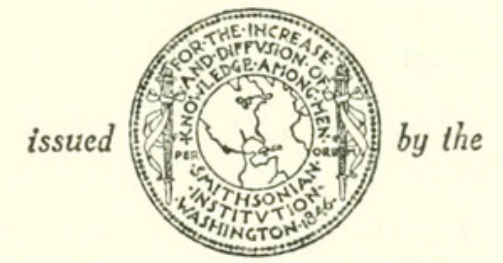

SMITHSONIAN INSTITUTION

U. S. NATIONAL MUSEUM

\begin{tabular}{lll}
\hline \hline Vol. 108 & Washington : 1958 & No. 3402 \\
\hline
\end{tabular}

\title{
TAXONOMY AND NOMENCLATURE OF THREE SPECIES OF LONCHURA (AVES : ESTRILDINAE)
}

\section{By Kenneth C. Parkes ${ }^{1}$}

In August and September 1956 I collected birds for a virus research project in central Luzon, Philippine Islands. The museum skins and skeletons prepared as a by-product of this project are now in Carnegie Museum, and represent the first modern collection of Asiatic birds in that institution. Virtually all of the work, therefore, of identifying these Philippine specimens has been done at the American Museum of Natural History (AMNH) and the U. S. National Museum (USNM). In connection with these more-or-less routine identifications, a certain amount of revisionary work proved to be necessary for certain species, several with ranges extending far beyond the Philippines. It has been thought desirable to publish such findings separately rather than include them in the final report of the 1956 collection, where they would be more-or-less irrelevant. The present paper treats the three species of the large estrildine genus Lonchura whose ranges include the Philippines.

The field work was carried out as part of a project of the Graduate School of Public Health, University of Pittsburgh, under the sponsorship of the Commission on Viral Infections, Armed Forces Epidemiological Board, and supported in part by the Office of the Surgeon General, U. S. Department of the Army. Specimens were collected and prepared with the invaluable assistance of Mr. Telesforo Oane and the generous counsel of Dr. Canuto G. Manuel, both of the 
National Museum of the Philippines. Much of the taxonomic work was carried out at the American Museum of Natural History, where I received many courtesies from Drs. Dean Amadon and Charles Vaurie, and at the U. S. National Museum, with the help of Mr. H. G. Deignan. Additional specimens were borrowed through the kindness of Dr. Raymond A. Paynter, Jr., of the Museum of Comparative Zoology, Dr. Austin L. Rand of the Chicago Natural History Museum, Dr. S. Dillon Ripley, Jr., of the Yale Peabody Museum, and Dr. Dwain W. Warner of the Minnesota Museum of Natural History.

\section{Lonchura leucogastra (Blyth)}

Three subspecies of the white-breasted mannikin are currently recognized: Lonchura leucogastra leucogastra (Blyth) of Siam, the Malay Peninsula, and Sumatra; L. l. everetti (Tweeddale) of the Philippines and northern Borneo; and L. l. castanonota Mayr of southern Borneo. Delacour (1943, p. 82) has shown that Lonchura leucogastroides (Horsfield and Moore) of Sumatra, Java, Bali, and Lombok, formerly considered to be a subspecies of L. leucogastra, is not closely related to the latter species.

Tweeddale described the Philippine everetti (type locality Monte Alban, Luzon) in 1877, and later (1878, p. 622) commented that specimens from Palawan appeared to be intermediate between everetti and leucogastra. He assigned them to the former, working under a strictly binomial system. After having examined over 60 Philippine specimens (this species is by far the least common Philippine Lonchura), I have come to the conclusion that the name everetti should be confined to the birds of Luzon and a few adjacent islands. The remainder of the range hitherto ascribed to everetti is occupied by a form which, although intermediate in many respects between everetti and leucogastra, occupies such an extensive range that I feel it merits recognition as an additional subspecies, which may be called

\section{Lonchura leucogastra manueli, new subspecies}

TYPE: USNM 201273; adult male; "near Isabella" [=Isabela], Basilan Island, Philippine Islands; Jan. 26, 1906; E. A. Mearns, collector (original No. 13903).

Diagnosis: Similar to $L . l$. everetti and $L$. $l$. leucogastra, but, in general, more deeply colored than the former, less deeply colored than the latter (details below); bill (except for Palawan birds; see measurements) averaging larger than that of either subspecies; wing averaging longer than that of leucogastra. Although in some characters manueli displays a condition intermediate between everetti and leucogastra, in others it presents a combination of characters typical of one subspecies or the other with a remarkable constancy 
considering the size of its range. In detail, then, the features distinguishing the three races under consideration are as follows.

The anterior underparts of everetti are chocolate brown, becoming deeper and richer on the chin and throat. In manueli this deep, rich color prevails, deepening almost to black on the chin and throat. Finally, in leucogastra the whole anterior underparts are virtually black. Dorsally there is a corresponding but less striking deepening: of the general brown color of crown and back.

In everetti and manueli the border between the dark breast and white abdomen includes many dark-tipped white feathers, giving this border area a distinctly spotted appearance. Such feathers are lacking in leucogastra, in which the border is more clear-cut.

In everetti the upper tail coverts are plain brown, somewhat darker than the rest of the upperparts. In manueli the upper tail coverts are decidedly blackish, contrasting quite sharply with the rest of the back. Finally, in leucogastra the upper tail coverts are black and this dark area has advanced to include the rump as well. The under tail coverts and thighs show a corresponding progression from brown to blackish brown to black in the three subspecies. The white shaft-streaks of the dorsal surface are best developed in everetti, somewhat reduced in manueli, and decidedly reduced in leucogastra, particularly on the head.

The tiny feathers along the metacarpal edge of the wing are predominantly white in everetti, predominantly dark brown or black in manueli and leucogastra. This is a matter of shifting proportions of white and pigmented feathers rather than a progressive intensification of pigmentation as in other color characters cited.

The yellow of the edges of the central rectrices, while variable, is a warmer, more golden color in leucogastra than in either manueli or everetti.

$R_{A N G E}$ : Southern half of Philippine Archipelago (see list of specimens for specific islands) and highlands of northern Borneo. The Tutong River specimen mentioned by Mayr (1938, p. 45) has been examined and belongs with manueli as might be expected. Six other Borneo specimens examined also belong here; one from Laham, eastern Borneo, and five from Sarawak (Poeh Mountain, Kelabit Plateau, headwaters of Baram River). In the diagnosis above, no comparisons have been made with the rather isolated $L$. l. castanonota Mayr of southern Borneo; this is a distinctive race with much richer coloring, being deep rufous chestnut above and jet black below.

Remarks: The only islands of the Philippines from which I have examined specimens which were not immediately referable to either L. l. everetti or L. l. manueli are Sibuyan and Culion; birds from these islands are almost exactly intermediate. It is possible that such 
intermediate populations may also be found on others of the central islands.

Although, as mentioned above, manueli is quite constant in its characters for a bird whose range encompasses so many islands, there is a certain amount of intraracial variation present. The most noticeable of these variations is a tendency for Palawan specimens to have smaller bills than those of the other islands within the range of manueli as here defined. The two specimens examined from the Sulu Archipelago are also small-billed. That this does not represent a stage in a cline toward the small-billed leucogastra is shown by the fact that the Borneo specimens have bills fully as large as those of typical manueli.

This subspecies is named for Dr. Canuto G. Manuel, chief of the zoology division of the National Museum of the Philippines, whose assistance and hospitality added immeasurably to the success of our expedition.

A series of specimens of Lonchura leucogastra from Kuching, Sarawak, sent to the U. S. National Museum for identification by B. E. Smythies of the Sarawak Museum, shows that a race is found in that vicinity which differs remarkably from other Borneo birds; no less than three races of this species are thus found in Borneo. The birds of the highlands of northern and eastern Borneo are L. l. manueli; those of southern Borneo, L. l. castanonota. The Kuching birds are actually closest in appearance to the geographically distant $L . l$. everetti of the northern Philippines. Mr. H. G. Deignan, who had suspected that the Kuching series differed from everetti as previously understood, has generously permitted me to include a description of this race in the present paper. I am happy to use the name which had been selected by Mr. Deignan, and designate this subspecies

\section{Lonchura leucogastra smythiesi, new subspecies}

Type: USNM 461688; adult male; Tabuan, Kuching, Sarawak; Dec. 9, 1938; collected for Sarawak Museum.

Diagnosis: Nearest to the geographically distant $L$. $l$. everetti of the northern Philippines, but white shaft-streaks of dorsal surface reduced, practically absent on crown; upper tail coverts virtually concolorous with back instead of a darker brown; anterior underparts deeper brown. The neighboring $L$. $l$. manueli of the highlands of northern Borneo has blacker anterior underparts and the upper tail coverts decidedly blackish, as mentioned above. The wing of $L$. $l$. smythiesi averages shorter than that of typical manueli, but matches that of the slightly smaller Palawan population assigned to the latter race. 
RANGE: Known only from the vicinity of Kuching, Sarawak, Island of Borneo.

Specimens examined (adults only):

L. . everetti: Luzon, 5; Catanduanes, 2 ; Polillo, 5; Mindoro, 1.

L. l. everetti $\mathrm{x}$ manueli intermediates: Sibuyan, 6 ; Culion, 2 .

L. l. manueli: Negros, 8; Cebu, 4; Bohol, 3; Siquijor, 1; Mindanao, 4; Basilan, 5; Palawan, 12; Tawi-tawi, 2; northern Borneo, 7.

L. l. smythiesi: vicinity of Kuching, Sarawak, 11.

L. l. castanonota: southern Borneo, 5 .

L. l. leucogastra: Siam, 3; Malay Peninsula, 6; Sumatra, 2.

Measurements: All measurements were taken to the nearest halfmillimeter. The wing was pressed flat against the ruler. The "bill index" is the sum of the culmen length and the greatest width of the bill. This index is an attempt to indicate the general "largeness" of the bill rather than merely the customary length figure. Perhaps the most obvious difference in dimension between large-billed and smallbilled birds is that of depth at the base, but no satisfactory comparable measurements could be made of this because of the great variation in degree of bill closure effected by preparators. The plus sign (+) indicates that the wing or tail was worn, and that the true measurement would be perhaps a millimeter or so longer. Measurements of excessively worn wings or tails were not taken.

L. l. everetti

Luzon: Wing, 51, 52, 52, 52, 53. Tail, 36, 37, 38, 39. Bill Index (B. I.), 19, 19.5, 20, 20, 20.

Catanduanes: Wing, 50, 51. Tail, 36, 38. B. I., 20, 20.

Polillo: Wing, 50, 50, 51, 51+, 52. Tail, $35+, 35+, 36,37$. B. I., 19.5 $19.5,20,20,20.5$.

Mrndoro: Wing, 52.5. Tail, 39. B. I., 19.5.

L. $l$. everetti $\mathrm{x}$ manueli intergrades

Sibuyan: Wing, 51, 51.5, 52, 52, 52, 52.5. Tail, $36.5,37,37,37.5,38+, 39.5$. B. I., 19, 19.5, 19.5, 21, 21, 21.

Culion: Wing, 51, 51.5. Tail, 35.5, 37.5+. B. I., 20, 20.

L. l. manueli

Negros: Wing, 50.5, 51.5, 52, 52, 52.5, 52.5, 52.5+, 53 . Tail, $36+, 38,40,41$. B. I., 20.5, 20.5, 20.5, 20.5, 21, 21.

Ceвu: Wing, 52, 53.5, 53.5, 55. Tail, $39+$, 40. B. I., 20.5, 21, 22.5, 22.5.

Siquijor: Wing, 52. Tail, 37. B. I., 20.

BoHoL: Wing, 52.5, 55, 55. Tail, 37.5, 41. B. I., 20.5, 2i.5, 22.

MindanaO: Wing, $52.5,53,54$. Tail, $37,37.5+, 38.5+$. B. I., 20.5, 21, 21.5, 22.

Basilan: Wing, 51, 51.5, 52.5, 53, 53.5. Tail, 35+, 36+, 36.5, 38+, 39. B. I., 19.5, 20.5, 21, 21.5, 22 .

Palawan: Wing, $49,50,50.5+, 51,51,51,51,51.5,51.5,52,53,53$. Tail, $34+, 34+, 36,37+, 37.5,37.5+, 38$. B. I., $19,19,19,19,19.5,19.5,19.5$, $19.5,19.5,20,20,20.5$.

TAWI-TAWr: Wing, 50.5, 52.5. Tail, $36+, 37+$. B. I., $19,19.5$.

Borneo: Wing, 50.5+, 51, 54. Tail, $34+, 36.5$. B. I., 20, 20, 21. 


\section{L. l. smythiesi}

SARAWAK: Wing, 50, 50, 50.5, 50.5, 50.5, 51, 51, 52, 52, 52, 52. Tail, 35, 36, $37,37,37.5,38 . \quad$ B. I., 19, 20, 20, 20.5, 20.5, 20.5, $21,21$.

L. l. leucogastra

Siam: Wing, 49, 49, 49.5. Tail, 33.5, 34, 37. B. I., 17.5, 17.5, 17.5.

Malay Peninsula: Wing, 48.5, 50, 50, 50.5, 50.5, 50.5. Tail, 34.5, 35, 35+, $35.5,35.5,36.5$. B. I., 17, 17.5, 18, 18, 18.

Sumatra: Wing, 49.5, 52.5. Tail, $35.5,37$. B. I., 17.5, 17.5.

\section{Lonchura punctulata (Linnaeus)}

Linnaeus (1758, p. 173) originally described the nutmeg mannikin as Loxia punctulata, listing its range simply as "Asia." His description was based entirely on the description and plate of Edwards $(1743$, p. 40$)$. In the 12 th edition of the "Systema Naturae" (1766), Linnaeus added a reference to Brisson, who specifically mentioned Java. Kloss (1931, p. 364) considered that Linnaeus thus acted as his own "first reviser," and that the type locality of Loxia punctulata should be restricted to Java. Hellmayr (1914, p. 60) had earlier come to the same conclusion. This is at variance with the treatment of Baker (1926, p. 91 ; 1930, p. 223) and other authors who have used the Linnaean name for the Indian rather than the Javanese race.

The identification of Linnaeus' name punctulata with a particular population of the nutmeg mannikin must rest entirely on Edwards' description and plate, since this was the sole reference in the 10th edition of the "Systema Naturae." If this description and plate are identifiable as one of the subspecies of Lonchura punctulata, any subsequent restriction by Linnaeus or anybody else is superfluous. Examination of Edwards' plate and accompanying description make it evident that it cannot possibly apply to the Javanese form, but must be that of India, as advocated by Baker. The evidence is as follows:

1. "The bill is of the shape and bigness of our Green-finch's bill . . ." The plate clearly shows a large-billed form of L. punctulata; the Indian bird is largebilled, the Javanese small-billed. Culmen length of Chloris chloris (England), $13 \mathrm{~mm}$.; Indian Lonchura punctulata, $11.5 \mathrm{~mm}$; Javanese L. punctulata, $10 \mathrm{~mm}$.

2. Although too much reliance should not be placed in Edwards' statement that the bird is figured in its natural size, still the wing-length of the figure matches Indian specimens exactly, and is far larger than Javanese specimens.

3. "Head, neck, beginning of the breast, back, wings and tail, are of a dark reddish brown . . ." True of all except the tail of the Indian race; the Javanese bird has the dorsal surface dull grayish brown, not dark reddish brown.

4. As for the tail, which is described and figured as "dark reddish brown," this does not match any form of the species, and is certainly not the Javanese bird in which the tail is distinctly ashy gray. The shape of the tail in the plate is also inaccurate, unless the specimen portrayed lacked the long pointed central rectrices, which are yellow in the Indian bird. A specimen of the Indian race in which the bright yellow, pointed central rectrices were missing, and in which 
the remaining rectrices were worn (as they appear to be in Edwards' figure) would appear to have a brownish tail.

5. "The forepart of the neck has something of a purplish cast"; true of the Indian race, not of the Javanese.

6. "The rump is of a lighter greenish brown." The rump of the Indian bird is decidedly yellowish or greenish, with faintly indicated darker markings as shown on Edwards' plate. The rump of the Javanese bird is heavily barred with dark gray and white, with no trace of yellowish or greenish.

7. The edges of the white abdominal feathers are described and figured as black; in the Javanese form these edges are dark brown, not black.

8. "The middle of the belly, thighs, lower belly and covert-feathers under the tail, are light brown, or dirty white." Exactly true of the Indian race; the thighs and under tail coverts of the Javanese race are white, heavily barred with dark gray.

The name of the Javanese race thus reverts to Lonchura punctulata nisoria (Temminck), while the Indian form is L. p. punctulata (Linnaeus). Stuart Baker gives the restricted type locality as Calcutta. Hodgson's $L$. p. lineoventer from Nepal, used for the Indian race by Kloss (1931), Stanford and Ticehurst (1938, p. 611), and others, is a synonym of punctulata.

L. p. topela (Swinhoe), with type locality Amoy, has customarily been considered the form which occurs in the mountains of Yunnan and northeastern Burma, although its status in the latter area has been questioned (Smythies, 1953, p. 231). La Touche (1927, p. 295), under topela, states: "In eastern Yunnan it is represented by another race, probably more closely akin to the Indian forms." All of the literature on Yunnan birds I have been able to find, however, lists the resident race as topela. The form found in most of Burma except the northeastern section is L. p. subundulata (Godwin-Austin).

In any case, the Yunnan-northeastern Burma bird does differ from topela, as might be anticipated on geographic grounds. The latter race is found in Taiwan and Hainan, and in eastern China and northeastern Indochina. It is the second-palest of the races of L. punctulata, being exceeded in this respect only by the Philippine race L. $p$. cabanisi.

The Yunnan bird may be described as follows:

\section{Lonchura punctulata yunnanensis, new subspecies}

Type: AMNH 720698; adult female; "hills around Tengyueh" [=Tengchung], western Yunnan, alt. 6,000 feet; June 1924; George Forrest, collector (original No. 5027).

Diagnosis: Similar to L. p. topela (Swinhoe), but coloration markedly richer; pencilling of ventral feathers darker and coarser; dark throat-patch warmer, more reddish brown; dorsal coloration in general browner, less gray, with, in many specimens, a greater contrast between the whitish shaft streaks and the ground color of the 
feathers. The yellow of the upper tail coverts and central rectrices averages deeper, less greenish. In juvenal plumage, L. p. yunnanensis is everywhere brighter, less grayish in color than topela. There is no significant difference in size between yunnanensis and topela. Measurements of type: wing (flat), $54 \mathrm{~mm}$.; tail, $39 \mathrm{~mm}$.; culmen, 11 $\mathrm{mm}$.; tarsus, $13 \mathrm{~mm}$.

Differs from L. p. subundulata (Godwin-Austin) of Assam and southern Burma in having more conspicuous light shaft streaks on the dorsum, a browner (less blackish) tone ventrally, and ventral markings of quite a different shape; the breast and flanks of subundulata have a spotted appearance, while those of yunnanensis are pencilled like those of topela. The posterior border of the brown throat of subundulata is more sharply defined than that of yunnanensis. Actually the population which is currently known as subundulata is a variable series of intermediates between the well-defined punctulata to the west and the yunnanensis-topela group to the east.

RANGE: Mountains of Yunnan and northeastern Burma (for localities, see list of specimens examined).

Remarks: Four specimens from Mengtz, in southeastern Yunnan, appear to be somewhat intermediate between L. p. topela and L. p. yunnanensis, although closer to the latter. Three of the four, however, are in such worn plumage as to make color comparisons almost valueless.

Smythies (1953, p. 231) writes: "The status of topela [in Burma] is uncertain; a single specimen obtained by the Vernay-Hopwood expedition at Singhaling Hkamti may have been a winter visitor, whereas birds seen at 5,000 feet or more in the Sadon hills and in the Ngawchang valley and not collected may have been resident topela; Stuart Baker claims that it occurs in the Shan States."

The Vernay-Hopwood specimen, taken on Mar. 4, 1935, is in the middle of the post-juvenal molt. A specimen (AMNH 720672) taken at Sinlumkaba, east of Bhamo, on Apr. 19, 1908, has almost completed the post-juvenal molt. Both are referable to yunnanensis. That this subspecies does, indeed, breed in northeastern Burma is suggested by a specimen (USNM 377788) taken 6 miles north of Myitkina on May 24, 1945, and one (AMNH 347218) taken at Myitkina on June 25, 1945. The specimen from Washaung (near Myitkina) mentioned by Stanford and Mayr $(1941,355)$ is, of course, yunnanensis rather than subundulata. It was taken on Apr. 12, 1939 , and is in about the same stage of the post-juvenal molt as the Singhaling Hkamti specimen.

Baker (1930,223) lists Munia inglisi Hume in the synonymy of L. p. topela; however, inglisi was named from Cachar, and birds from this region are referable to L. p. subundulata. 
L. p. catervaria Koelz (1954, p. 19), described from the Khasia Hills, represents a population intermediate between punctulata and subundulata, and is best placed in the synonymy of the latter. It will be remembered that subundulata itself represents a rather variable intermediate population.

Specimens examined:

L. p. yunnanensis: Yunnan: Vicinity of Tengyueh, 23; Nantien, 1; ShweliSalaween Divide, 6. Burma: Myitkina, 1; 6 miles north of Myitkina, 1; Singhaling Hkamti, 1; Washaung, 1; Sinlumkaba, 1.

L. p. yunnanensis $\mathrm{x}$ topela intermediates: Yunnan: Mengtz, 4 .

L. p. topela: Taiwan, 40; Hainan, 23; Fukien, 6; Kwangtung, 1; Tonkin, 5; Annam, 2.

L.p. topela $\mathrm{x}$ subundulata intermediates: Burma: Pegu, 2 .

L. p. subundulata: Assam, 5; Khasia Hills ("catervaria"), 10.

Also series of other races in USNM and AMNH.

\section{Lonchura malacca (Linnaeus)}

Delacour (1943, p. 83) united three groups of forms which had often been considered separate species: L. malacca, L. ferruginosa, and $L$. atricapilla. He used the name ferruginosa for the combined species, overlooking the fact that Loxia malacca Linnaeus, 1766, antedates Loxia ferruginosa Sparrmann, 1789. The desirability of merging the three groups has been questioned by some authors, but I am not prepared to go into this question here. The present paper is concerned only with that portion of the combined species formerly known as Lonchura atricapilla, all forms of which lack white on the head and underparts.

It is tempting to consider L. grandis of New Guinea as part of this species, since the adults closely resemble the atricapilla group. Delacour (1943: p. 83) considered grandis and ferruginosa (=malacca) to comprise a superspecies, giving the large bill and extensively black underparts of grandis as specific characters. Even more important, in my opinion, is the pattern of the juvenal plumage, in which grandis differs markedly from all races of malacca in being streaked on the throat.

Salomonsen (1953, p. 265) pointed out that a revision of this species was badly needed, and he reviewed it briefly himself. The large area ascribed by Salomonsen and other authors to the race atricapilla involves a number of well-marked clines, which can be divided into several subspecies and intergrades. Salomonsen's treatment of the Philippine populations is critically discussed (p. 290) after a review of the mainland forms.

The distribution of $L . m$. sinensis is substantially as given by Salomonsen (1953, p. 266), namely Malay States, southern Siam, and lowlands of Sumatra. The diagnostic characters can, how- 


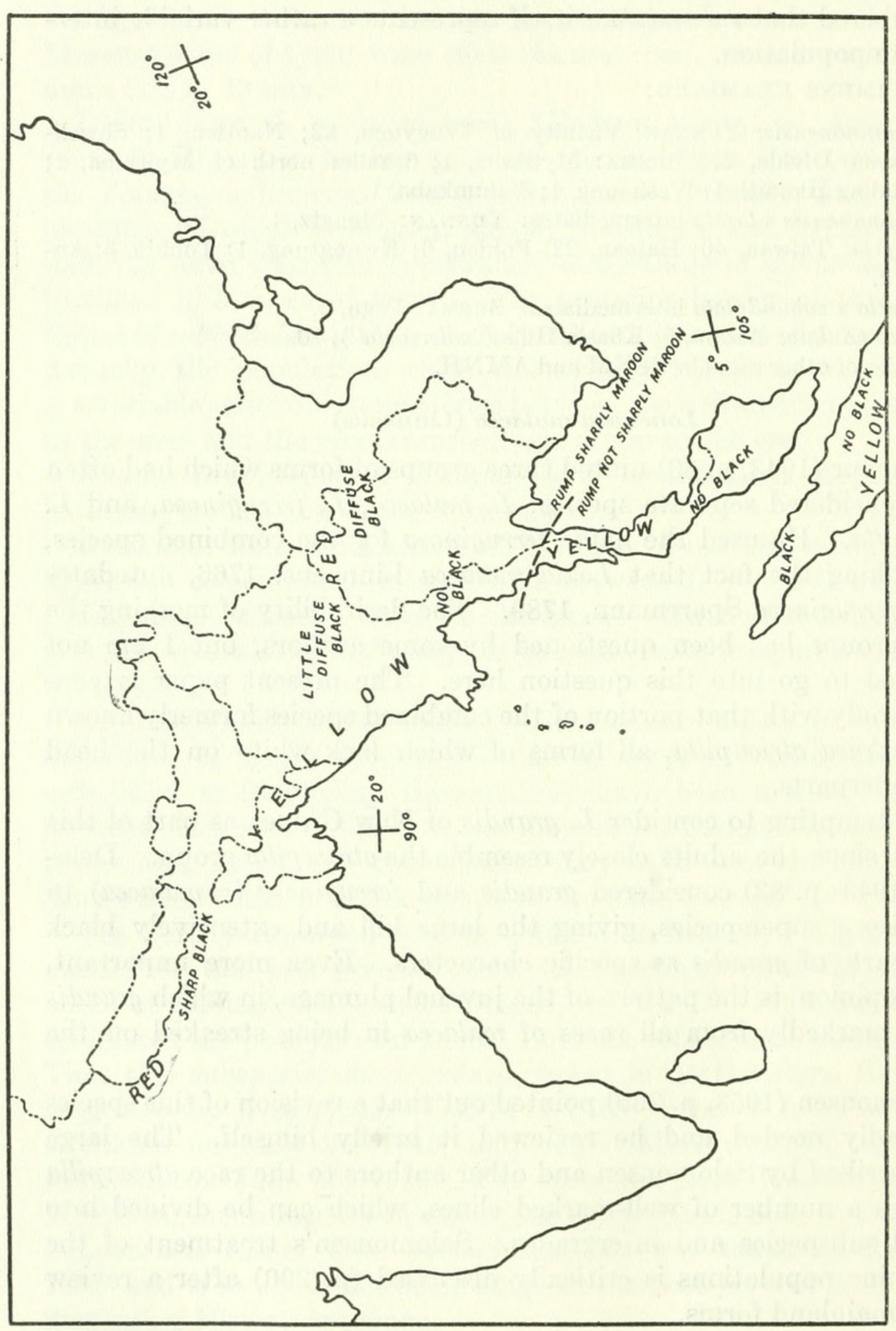

동 흥

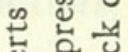

อ ก

$=\frac{\mathrm{d}}{\mathrm{B}}$

సี छ

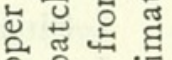

늠 궁

虫 洁

늠ํำ

잉 $\rightarrow$

됴

픈 정

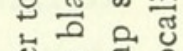
임으 $\therefore$ 出 3 요 을 岕 క 골 政范 ర్ల స 心 닌 . N ن ปั

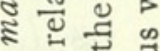
¿ \& \& 무응 స్ 글 a 3 . 으 질

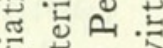
స్

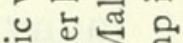

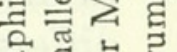

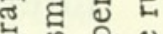
क. 政 ఏ $\dot{0}$ क. क क 넝 년. 넌 |. 茨. 엄 जू 
ever, be expanded. The black abdominal patch is absent. The back is paler (particularly noticeable in fresh plumage) than that of adjacent populations to the north and west. The rump is darker and more reddish than the back, but this color is much paler and more diffuse than in any of the races to the north. The upper tail coverts and central rectrices are yellow. The race L. m. batakana (Chasen and Kloss) from the mountains of northern Sumatra is similar in dorsal color (including rump and tail), but smaller, and with a welldefined black abdominal patch.

Toward the northwest, sinensis intergrades with atricapilla, as suggested by Chasen and Kloss (1929, p. 23). A specimen from Pegu is precisely like sinensis above and below, except that the rump is a deeper maroon and quite sharply defined. Another Pegu specimen is similar dorsally, but blackish on the lower abdomen and under tail coverts. Specimens from northern Burma and northwestern Yunnan resemble atricapilla in having the tail and coverts yellow, and a well-defined maroon rump patch; the Yunnan specimens are paler than those of Burma. Ventrally these birds are rather variable, but all have a more-or-less diffused blackish area in the lower abdomen.

In Assam and Bengal occurs true atricapilla, which has a welldefined black abdominal patch, deep maroon rump, and yellow tail and coverts.

Salomonsen (1953, p. 266), Smythies (1953, p. 229), and others have synonymized Munia rubro-nigra Hodgson (Nepal) with atricapilla of Bengal. This is understandable in view of the distributions and distinguishing characters for the two claimed by Stuart Baker (1926, pp. 80-81). Both are incorrect. As pointed out by Vaurie (1949, p. 38) and others, rubro-nigra does not differ from atricapilla in wing length or color of underparts. Judging from a limited amount of material, however, the name rubro-nigra is available for a well-marked race of Nepal and adjacent India. It occurs at least as far east as Jainagar, on the Nepal-Bihar border (specimen, Yale Peabody Mus. 26520, slightly intermediate toward atricapilla), and as far west as Dehra Dun. It resembles atricapilla in having a well-defined black abdominal patch and sharply defined maroon rump, but the long, dissected upper tail coverts are a rich maroon red, little different from the rump, whereas in atricapilla these feathers are golden yellow to orange. The rectrices themselves are washed with yellow in atricapilla, deep reddish brown in rubro-nigra. The latter race is also slightly paler dorsally. The four rubro-nigra seen have quite large and heavy bills, but accurately sexed material is insufficient to determine whether there is any actual difference between the two races in this respect. 
The population of Chieng Rai, northernmost Thailand, mentioned by Deignan (1945, p. 559), is somewhat variable, but cannot be satisfactorily assigned to either a known race or an intergrade between races. Rather than to try to stretch the limits of well-defined subspecies to include these birds, it would seem advisable to recognize them as a subspecific entity, for which an appropriate name is

\section{Lonchura malacca deignani, new subspecies}

Type: USNM 350467; adult male; Chieng Rai, northern Thailand (1,214 feet); May 8, 1936; H. G. Deignan, collector (original No. $1297)$.

Diagnosis: Differs from all other subspecies of the mainland, glossy black-headed group except rubro-nigra in that the long upper tail coverts and central rectrices in most (not all) specimens are deep orange-red rather than some shade of yellow. In a minority of individuals these feathers are rich yellow-orange, not unlike (but somewhat more intensely colored than) those of atricapilla. All individuals of deignani, however, may be distinguished from rubronigra or atricapilla by their more diffuse and generally less blackish abdominal patch, and by having dark brown rather than black under tail coverts. The general color of both dorsal and ventral surfaces is also a paler reddish brown in rubro-nigra than in deignani.

RANGE: Chieng Rai Province, northern Thailand, and probably Indo-China. A single specimen from Hue, Annam, is referable to deignani. A series of specimens from Hainan in the American Museum of Natural History consists of cage birds, as shown by the condition of the claws; the species is not known to occur in Hainan in a wild state. However, these specimens may well have originated on the Indo-China mainland across from Hainan, since they agree in every respect with deignani.

Specimens examined (mainland and Sumatra races):

L. m. rubro-nigra: Nepal, 1; Nepal-Bihar border, 1; United Provinces, 2.

L. m. alricapilla: Assam, 5 .

L. $m$. atricapilla $\mathrm{x}$ sinensis intermediates: northern Yunnan, 5; northern Burma, 2; central Burma, 2; southern Burma, 2.

L. $m$. sinensis: Malay Peninsula, 2; Sumatra, 1 .

L. $m$. batakana: Sumatra, 2 .

L. m. deignani: northern Thailand, 6; Annam, 1; "Hainan" (cage birds), 8.

Leaving the glossy black-headed birds of the mainland, we turn now to the eastern populations inhabiting Taiwan, the Philippines, Celebes, and Borneo. There is a general cline in the direction of increased saturation of the pigment of head and breast running from north to south, from grayish brown in Taiwan to rich black in Borneo and northern Celebes; then, surprisingly, back to brown again in 
southern Celebes (L. m. brunneiceps). The pale northern extreme is L. m. formosana (Swinhoe). Salomonsen (1952, p. 354) has shown that specimens from northernmost Luzon are inseparable from Taiwan examples of formosana. The rest of the birds from central Luzon to Borneo have until lately been considered to be L. m. jagori (Martens), type locality restricted by Salomonsen (1953, p. 267) to Manila. As represented in the Philippines, jagori is actually a tremendously variable series of intermediates between formosana and the almost consistently black-headed Borneo population. Salomonsen endeavored to express this by describing the black-headed birds as $L . m$. gregalis, with type locality Opol, Mindanao. This merely complicated matters, however, because birds from the range ascribed by Salomonsen to his "gregalis" are not consistent in having dull black rather than dark brown heads, as he claims. Three Sulu birds in the American Museum of Natural History, for instance, have distinctly brownish crowns, and even some of the Borneo specimens (cf. AMNH 720576, Labuan) tend to have rather brownish heads. In a series of 18 specimens from Basilan, which should be "gregalis" (University of Michigan Museum of Zoology), there is much variation; although mostly black-headed, several are distinctly brown on the crown and nape. Some of my own Luzon series (which is quite variable inter se) are as dark as any Borneo specimens seen. Peters (1940, p. 209) could detect no significant difference between Borneo and Philippine specimens of this species, calling both jagori. De Schauensee (1957, p. 11), on the other hand, upheld "gregalis," calling it "a very distinct race," on the basis of comparing one adult male and two immature females from Mindanao with three Luzon specimens!

Ideally we should probably use two names, one for the Taiwannorthern Luzon bird and one for the birds of Borneo and northern Celebes, with the rest of the Philippine birds considered as a variable intergrading cline. Unfortunately the name jagori was based on the highly variable population of central Luzon. In view of the fact that variability in this species is so high in this part of the world, so that few specimens could be named if their localities were unknown, it appears best to continue to use jagori in its traditional sense, considering gregalis Salomonsen as a synonym. The subspecies jagori thus includes both brown-headed and black-headed birds, with a preponderance of the latter toward the south, but no reasonable geographic line can possibly be drawn between them.

There seems to be no consistent geographic variation in Lonchura malacca within the Island of Borneo; this, of course, is in striking contrast to the situation in L. leucogastra. 


\section{Literature Cited}

Baker, E. C. Studart

1926. The fauna of British India, including Ceylon and Burma. Birds. Vol. 3, $\mathrm{xx}+489 \mathrm{pp}$.

1930. The fauna of British India, including Ceylon and Burma. Birds. Vol. 7, vii+484 pp.

Chasen, F. N., and Kloss, C. Boden

1929. Two new Malaysian birds. Bull. Raffles Mus., vol. 2, pp. 22-23. Deignan, H. G.

1945. The birds of northern Thailand. U. S. Nat. Museum Bull. 186,

Delacour, Jean $\mathrm{v}+616 \mathrm{pp}$.

1943. A revision of the subfamily Estrildinae of the family Ploceidae. Zoologica (New York), vol. 28, pp. 69-86.

De Schauensee, R. M.

1957. Notes on Philippine birds. Not. Nat. Acad. Nat. Sci. Philadelphia, No. 303, $12 \mathrm{pp}$.

Edwards, George

1743. A natural history of uncommon birds. Vol. 1, xxiii $+52 \mathrm{pp}$.

Hellmayr, C. E.

1914. Die Avifauna von Timor. Zoologie von Timor, 1. vi+ $112 \mathrm{pp}$.

KLOSS, C. Boden

1931. An account of the Sumatran birds in the Zoological Museum, Buitenzorg, with descriptions of nine new races. Treubia, vol. 13, pp. $299-370$.

Koelz, Walter

1954. New birds from Iran, Afghanistan, and India. Contr. Inst. Reg. Expl., vol. 1, pp. 1-32.

LA Touche, J. D. D.

1927. A handbook of the birds of eastern China. Pt. 4. Pp. 293-398.

Linnaeus, Carolus

1758. Systema naturae. Ed. 10, vol. 1, 824 pp.

MAYR, ERNST

1938. Notes on a collection of birds from south Borneo. Bull. Raffles Mus., vol. 14, pp. 5-46.

Peters, James L.

1940. Birds from Mt. Kina Balu, North Borneo. Bull. Mus. Comp. Zool., vol. 87, pp. 195-211.

Salomonsen, Finn

1952. Systematic notes on some Philippine birds. Vidensk. Medd. Dansk Naturh. For., vol, 114, pp. 341-364.

1953. Miscellaneous notes on Philippine birds. Vidensk. Medd. Dansk Naturh. For., vol. 115, pp. 205-281.

Smythies, B. E.

1953. The birds of Burma. Ed. 2, xliii $+668 \mathrm{pp}$.

Stanford, J. K., and Mayr, Ernst

1941 The Vernay-Cutting Expedition to northern Burma. Pt. 4. Ibis, ser. 14, vol. 5, pp. 353-378.

Stanford, J. K., and Ticehurst, C. B.

1938. On the birds of northern Burma. Pt. 4. Ibis, ser. 14, vol. 2, pp. 599-638. 


\section{Tweeddale, Arthur, Marquis of}

1878. Contributions to the ornithology of the Philippines. No. 9. On the collection made by Mr. A. H. Everett in the island of Palawan. Proc. Zool. Soc. London (1878), pp. 611-624.

\section{Vaurie, Charles}

1949. Notes on some Ploceidae from western Asia. Amer. Mus. Nov., No. 1406, $41 \mathrm{pp}$. 


\section{$2 \mathrm{BHL}$ Biodiversity Heritage Library}

Parkes, Kenneth C. 1958. "Taxonomy and Nomenclature of Three Species of Lonchura (Aves: Estrildinae)." Proceedings of the United States National Museum 108(3402), 279-293. https://doi.org/10.5479/si.00963801.108-3402.279.

View This Item Online: https://www.biodiversitylibrary.org/item/32559

DOI: https://doi.org/10.5479/si.00963801.108-3402.279

Permalink: https://www.biodiversitylibrary.org/partpdf/7091

\section{Holding Institution}

Smithsonian Libraries

\section{Sponsored by}

Smithsonian

\section{Copyright \& Reuse}

Copyright Status: NOT_IN_COPYRIGHT

Rights: https://www.biodiversitylibrary.org/permissions/

This document was created from content at the Biodiversity Heritage Library, the world's largest open access digital library for biodiversity literature and archives. Visit BHL at https://www.biodiversitylibrary.org. 